DOI : https://doi.org/10.24260/khatulistiwa.v9i1.1384

\title{
ANALYSIS OF KNOWLEDGE MANAGEMENT SYSTEM \\ IN THE BOOK OF FIQH MOBILE APPLICATION \\ BULUGHUL ISLAMIC LAW BASED ON USABILITY
}

\author{
Thoyyibah. T,1 Wasis Haryono, ${ }^{2}$ Tita Purnamasari, ${ }^{3}$ Dian Megasari ${ }^{4}$ \\ Universitas Pamulang \\ dosen01116@unpam.ac.id, ${ }^{1}$ wasish@unpam.ac.id ${ }^{2}$ \\ dosen01261@unpam.ac.id, ${ }^{3}$ dosen00519@unpam.ac.id ${ }^{4}$
}

\section{HIGHLIGHTS}

- The tudents can learn the science of religion through a mobile applicationcan.

- SUMI (Software Usability Measurement Inventory) as evaluation system

ARTICLE HISTORY

$\begin{array}{lll}\text { Submit } & : & \text { 25 Mar } 2019 \\ \text { Revision } & : & \text { 30 Mar } 2019 \\ \text { Revision } & : & \text { 30 Jun } 2019 \\ \text { Minor } & & \\ \text { Accepted } & : & \text { 30 Jun } 2019 \\ \text { Published } & : & \text { 04 Jul } 2019\end{array}$

\begin{abstract}
Mobile applications have become a good learning tool. This application involves technology that can be accessed anytime and anywhere. But keep in mind also the progress of science and technology can not be separated from the development, discovery and progress of science in the heyday of Muslims. Islam is very influential in the world and even a great deal of learning is applied to certain methods. The aim of this study was to analyze the mobile learning of the Book of Fiqih in the Islamic Law of the Bulughul Haram by mapping knowledge and evaluation of SUMI (the Usability Measurement Inventory). This study uses a method adopted from KMSLC (Knowledge Management System Life Cycle). The results of this study are mapping knowledge and measuring the quality of a system.
\end{abstract}

\section{Keyword : $\quad$ Mobile applications, Fiqih, SUMI, KMSLC (Knowledge Management System Life Cycle)}

Copyright $@ 2019$ The Authors. Pusblished by The Institute for Research and Community Service Pontianak State Institute for Islamic Studies. This is an Open Access article under of CC BY 4.0 license https://creativecommons.org/licenses/by/4.0/
KHATULISTIWA: Journal of Islamic Studies Vol. 9, No. 1. March 2019
DOI : https://doi.org/10.24260/khatulistiwa.v9i1.1384 Analysis of Knowledge Management... 


\section{A. INTRODUCTION}

Technological developments can change human character (Malik M, 2017). In addition, modern humans now depend on science and. Science is basically the thoughts of humans themselves (Muksin M, 2016). Lots of changes in humans because of the influence of increasingly sophisticated knowledge and technology (Bakhri A, 2015). Islam is a religion that is in accordance with human nature. Nevertheless, Islam supports people to find and develop science and technology (science and technology) (Dwijiwo AQNES, 2014). Islam gives appreciation to human reason (Imam, 2018) 7. Thus, education is a means to improve quality and become a benchmark for the progress of the nation (Mahfudin R, 2017). The limitations of space and time are no longer a barrier to the teaching and learning process (Setiawan A, Suryani N, Asrowi , 2017) . Technology provides services for human needs (Muslihudin M, 2017). Technology experiences rapid development for human life. The use of technology can be a healthy learning when the technology has a role as an educator (Saefulloh A, 2018). Especially mobile information can be used for learning media distribution (Ali N, Saputra E, Wulan R. 2016). This control produces technology products (Hamzah AR, 2016). This research is about the use of a mobile system in the learning process. The system that will be examined is the Application of the Book of Fiqih in Islamic Sciences of Bulughul Maram. A system is said to be useful when the system has a lot of knowledge. The method used in this study is Knowledge Management System Life Cycle (KMSLC). This method is adopted from the Knowledge Management System works (Awad EM, Ghaziri HM, 2011). This study also uses the Usability Measurement Inventory (SUMI) software questionnaire as a measure of the quality of a system.

\section{FIQH}

Fiqh is not a revelation from heaven. Fiqh is a product of human ijtihad (Iqbal MM, 2017). Freedom of reason and logic, the philosophy of Islamic law places it proportionally. Where is the reason with extraordinary potential to be freed to work and think in legal divorce under the auspices and guidance of revelation (Hamidi R, [Year Unknown]). The implementation of fiqh codified into applicable Islamic law in Indonesia does not cover all fields, only covers a number of fields, such as marriage, will, grant, inheritance, zakat, infaq, alms and sharia economics. The enactment of Shari'a or Islamic law in Indonesia existed before western law prevailed in the archipelago, but there are still many community misconceptions about Shari'a that apply in Indonesia (Islami I, Anisariza NU, Prasetyo KF, 2018).

KHATULISTIWA: Journal of Islamic Studies Vol. 9, No. 1. March 2019
DOI : https://doi.org/10.24260/khatulistiwa.v9i1.1384 Analysis of Knowledge Management... 


\section{KNOWLEDGE}

1. Knowledge

Knowledge consists of two types, namely tacit knowledge and explicit knowledge. According to Sarayreh et al. (2012) tacit knowledge is an insight and experience in individuals unknown that they use it actively or knowledge in the form of experience that exists in each individual. Whereas explicit knowledge is knowledge that can rationally be expressed in words, sentences, numbers or formulas as outlined in the form of books, documents, journals and others (Nonaka 1997). According to Turban et al. (2007) knowledge is the clarity of data and information into the context of information technology so that knowledge is stored in digital form. Besides that knowledge is information that is owned by individuals in the organization which can ultimately be beneficial to others (Randeree 2006). Connell et al. (2001) also said that knowledge is a source of competitive advantage that gives high priority to ensure that they get maximum benefits and gain knowledge where knowledge is built from data and data itself is a fact of observation or perception. In addition, knowledge is an intellectual asset where knowledge has characteristics such as the use of knowledge will not be exhausted, the transfer of knowledge has no limits and the amount of knowledge is abundant but limited, it will simply disappear so we need media to share knowledge (Sikki 2010).

\section{Knowledge Representation}

Knowledge representation is the method used as a means of acquiring knowledge from experts. The process of representation in data format so that it is easily understood by humans using computers so as to facilitate decision making (Turban et al. 2007).

\section{Knowledge Management}

According to Fernandez and Sabherwal (2010) knowledge management is the maximum result of the source of knowledge needed by someone. Knowledge management is also a process of knowledge management by means of capturing, storing, and disseminating knowledge using information technology media (Lai 2007). Besides that knowledge management is a field of study that can improve the process of sharing, channeling, creating, capturing and understanding knowledge so that knowledge is not in vain (Gottschalk 2006). Knowledge Management consists of a software system and integrates and disseminates information to users for the learning and decision making process (Rhem AJ 2006).

KHATULISTIWA: Journal of Islamic Studies Vol. 9, No. 1. March 2019
DOI : https://doi.org/10.24260/khatulistiwa.v9i1.1384 Analysis of Knowledge Management... 


\section{Knowledge Management System}

According to Fernandez and Sabherwal (2010), knowledge management systems are the integration of technology and mechanisms developed to support the knowledge management process. Knowledge management systems can be classified into four types, namely the application of knowledge, capturing knowledge, sharing knowledge, finding knowledge, then the knowledge contained in the system can be used in accordance with their respective fields.

\section{Capturing Knowledge}

Capturing knowledge is not an easy task. Knowledge taken can be in the form of documents or knowledge from experts. According to Awad EM, Ghaziri HM (2010) one definition of capturing knowledge is the transfer of knowledge from experts to a program. The technique used to capture knowledge namely On-Site Observation means observations made by interpreting and recording to solve a problem or observation in the field by bringing the developer closer to the real steps, techniques, and procedures used.

\section{Knowledge Codification}

According to Awad EM, Ghaziri HM (2010) Codification of knowledge means converting tacit knowledge into explicit knowledge used by members of the organization. Knowledge tools or procedures consist of:

1. Knowledge Map is a visual representation of a knowledge that is connected to one another in a series of processes.

2. Frames are a codification of knowledge through prior experience.

3. Production Rules are representations of knowledge which are popular forms of tacit knowledge. The rule used is a statement that determines the action to be taken in a particular case. The syntax is: IF (premise) THEN (action).

4. Case-Based Reasoning is a collection of cases that are solved by involving experts. Document many cases so that they can be used when there are similar cases.

\section{Usability}

Usability Engineering is an approach to software development or systems that includes user participation from the start until the product is referenced in Seffah A, Metzker E, 2009. So usability engineering is the stage of the use of a system for the viability of a system. According to ISO 9241-11-1998 usability is an assessment of the extent to which products can be used by users with measures of effectiveness, efficiency and satisfaction in the context of use. According to ISO 9241-11-1998 usability is an 
assessment of the extent to which products can be used by users with measures of effectiveness, efficiency and satisfaction in the context of use. Besides usability testing is one method used by users to see the level of user convenience in interacting with an information system (Baihaqi MAW, Rosidi A, Syahdan SA, 2016). To measure application satisfaction, SUMI (Software Usability Measurment Inventory) questionnaire was used, a questionnaire developed by Cork Collage University (Veenendaal E, 1998).

Usability is the interaction between the media and the user (Edwards PJ, Moloney PK, Jacko JA, Sainfort F, 2008). Planning The initial stage of the system uses usability and interfaces for users (Hafit H, Razak FAH, Haron H, 2011). Usability can be seen as one of the criteria to ensure the level of good and bad of a product and usability problems caused by a lack of knowledge that is often identified when first using the system (Barendregt W, MM Worker, Bouwhuis DG, Baauw E, 2006). Usability of software products has become a key factor in software quality (Abran A, Khelifi A, Suryn W, 2003).

Usability is one of the most important parts to know the characteristics of the quality of a system (Diah NM, Ismail M, Ahmad S, Dahari MKM, 2010). On the other hand usability as a quality attribute that assesses how easily the user interface is used, thus allowing users to develop tasks in a clear, transparent and useful manner (Nielsen J. 2012).

\section{A. METHOD}

The system development method used is the method adopted from the KM System Life Cycle found in Awad EM, Ghaziri HM (2010) second Edition. The method in Figure 1 consists of Analysis of Existing Infrastructure Evaluation, Knowledge Capture, Implement the KM system, Evaluation.

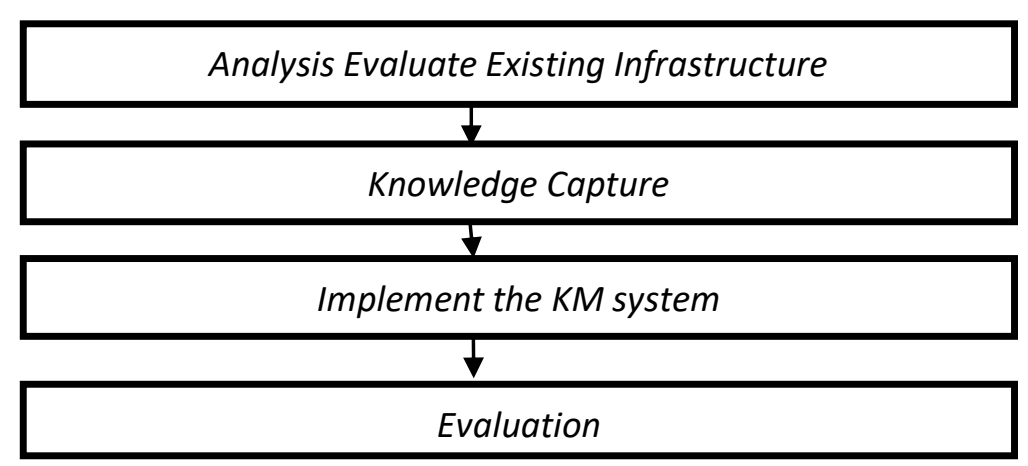

Figure 1 KM System Life Cycle

1. Analysis Evaluate Existing Infrastructure

This Evaluate Existing Infrastructure process is the first stage of the KM System Life Cycle. This process is carried out by looking at the characteristics of mobile information systems users..

2. Knowledge Capture

Knowledge Capture is done by creating a knowledge folder on the

KHATULISTIWA: Journal of Islamic Studies

Vol. 9, No. 1. March 2019
DOI : https://doi.org/10.24260/khatulistiwa.v9i1.1384

Analysis of Knowledge Management... 
application. Where each map is integrated and interconnected

3. Implement the KM system and usability evaluation

Implementing the KM system is done by doing a system screenshot.

4. Evaluation

Evaluation using the SUMI (Software Usability Measurement Inventory) questionnaire with 10 respondents.

\section{B. RESULT AND DISCUSSION}

\section{a. Analysis Evaluate Existing Infrastructure}

Analysis of system requirements, namely through analysis of data about the book of Fiqih and Islamic content.

\section{b. Knowledge Capture}

The map of knowledge designed in this system consists of the book of figh bulughul maram and Islamic content seen in Figure 2.

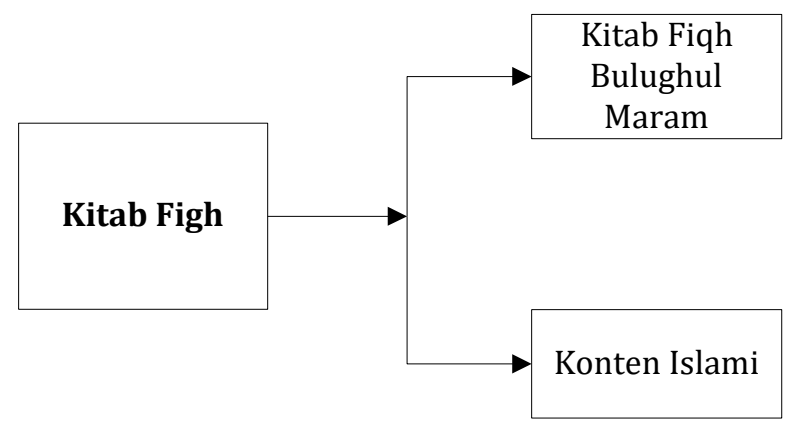

Figure 2. Knowledge Map the book of Figh

1. Knowledge Map of the Book of Fiqh Bulughul Maram

Knowledge Map of Fiqh bulughul maram in Figure 3 consists of the Book of Thaharah, the Book of Prayer, the Book of Bodies, the Book of Zakat, the Book of Shiam, the Book of Hajj, the Book of Sale, the Book of Marriage, the Book of Crimes, the Book of Jihad, the Book of Jihad, the Book of Graves, Kitan sumpahdan Nadzar, book breaking up, slave book, completeness book. 


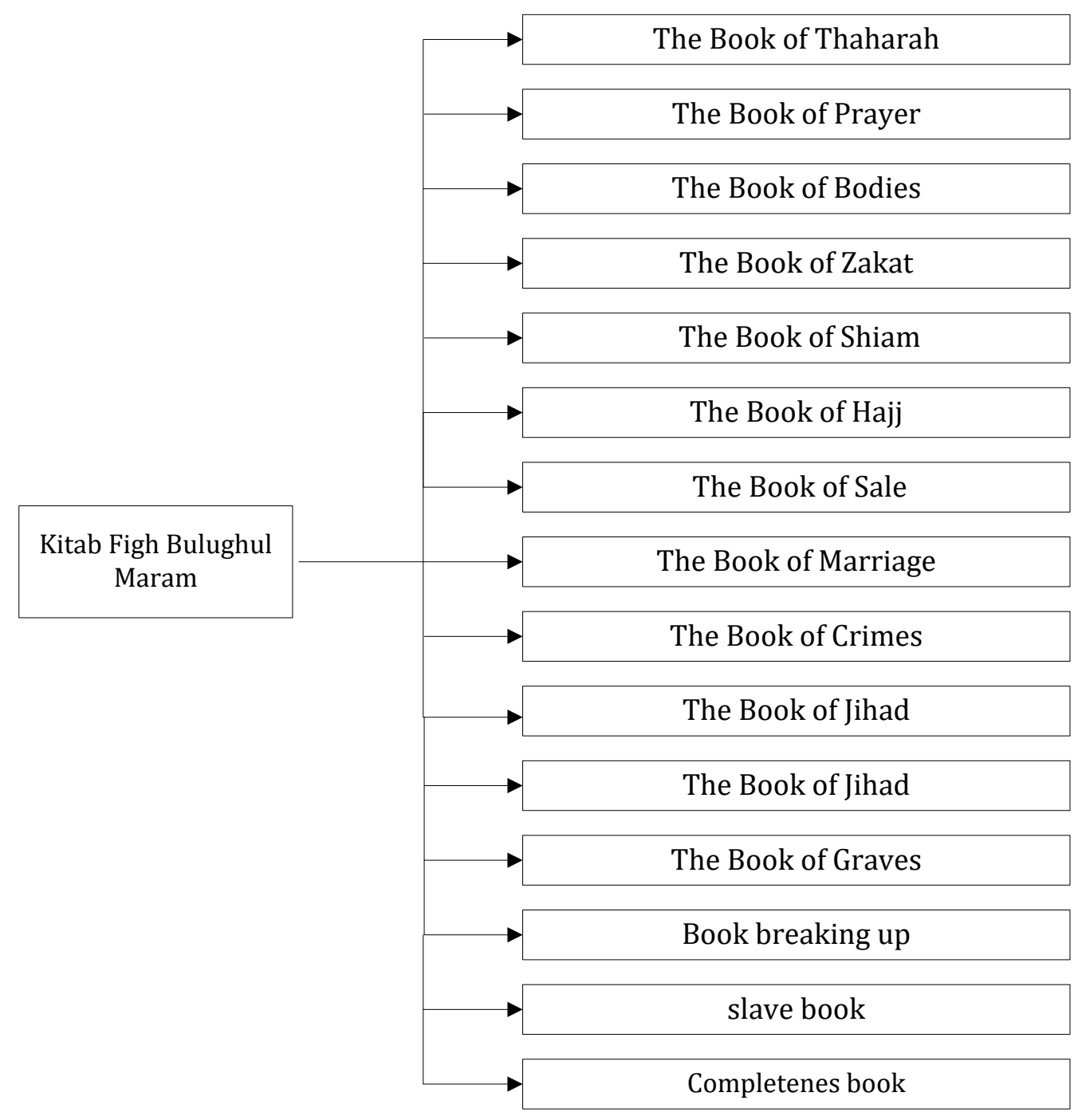

Figure 3. Knowledge Map Kitab Figh Bulughul Maram

2. Knowledge Map Islamic Content

Knowledge Map of Islamic Content in Figure 4 consists Al Quran and its translations, Islamic stories of choice, Four companions of Rasul Allah, Tajwid Sciences, Acts of 25 prophets and apostles, stories of Islamic wisdom, daily children's prayers, history of Prophet Muhammad Saw, Sheikh Abdul Qadir Jaelani, the example of the Prophet's best friend, Sholawat Nabi, Asmaul husna. 


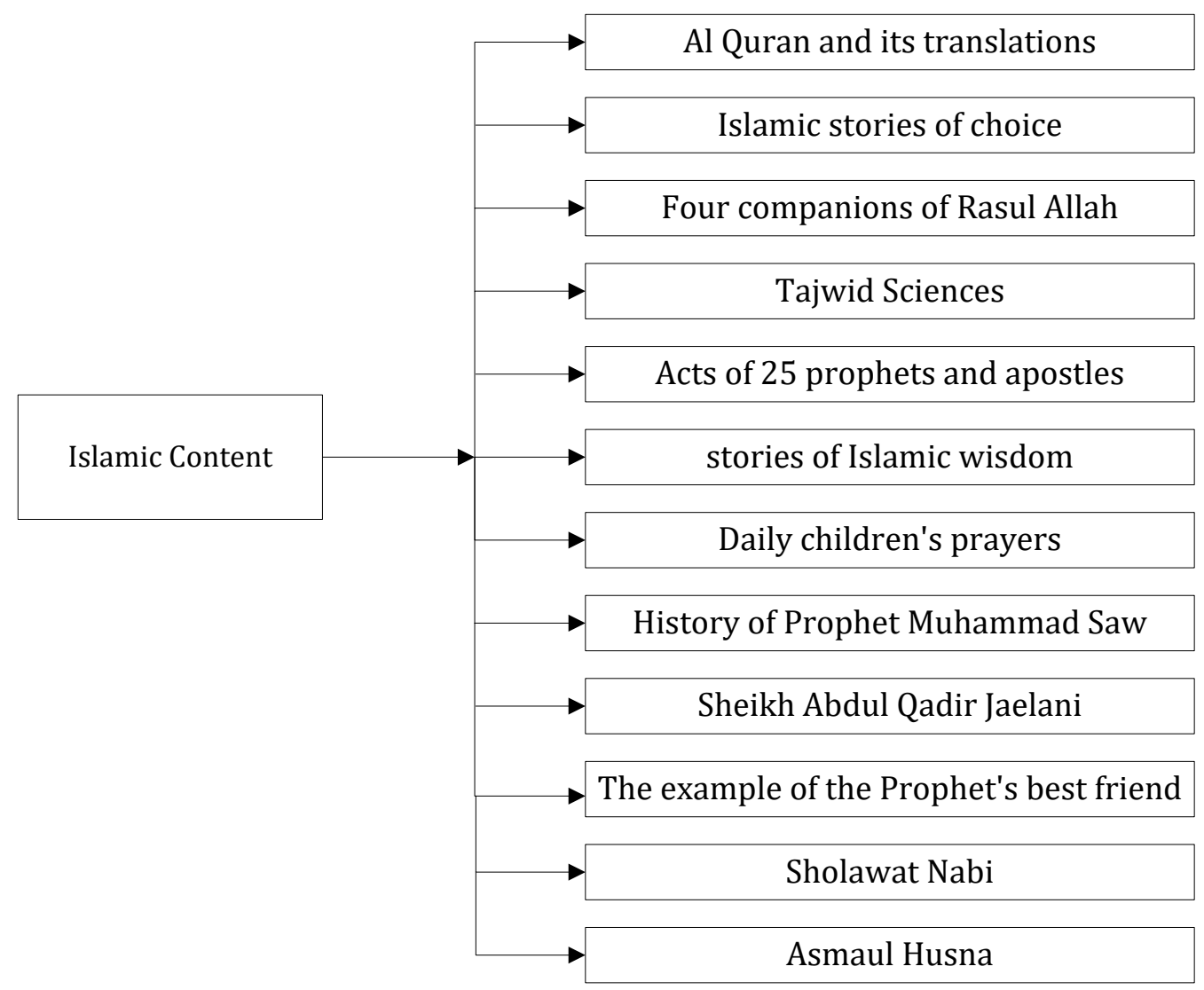

Figure 4. Knowledge Map Islamic Content

\section{c. Implement the KM System}

This book of fiqh mobile application is in the play store with email owner avfdcstudio@gmail.com. This mobile application is offline and lightweight and easy to use. The results of this application screnshoot consist of: 


\begin{tabular}{|l|l|l|l|l|}
\hline IImu Fiqih & Kitab Ilmu Fiqih & ( Cari Ribuan Konten Islami \\
\hline
\end{tabular}

Figure 5. Display of result kitab fiqh Bulughul Maram

\section{d. Evaluation}

The questionnaire used in the evaluation phase is SUMI (Software Usability Measurement Inventory). The score used for each response is different, namely 4, 2, 0 for the response to agree, do not know and do not agree with the categories of effectiveness, efficiency and satisfaction. The number of questions given to respondents consists of 30 questions that have 10 questions in each category.

After that the results in each category will be multiplied by 2.5 . The measurement of the SUMI questionnaire is in the form of a scale of 0-100. The final score of each category uses the median for each ordered value given by the respondent to get the usability results of a mobile system. According to SUMI's provisions, if the median measurement result is less than 50, it is still below the average. It can be seen in Effectiveness, Efficiency and satisfaction for Respondents are shown in Table 1, Table 2 , Table 3 . The results of calculations based on categories are in Table 4 . That the median score of each category is above the average of SUMI's provisions of $90,77.5$, and 70 which means that usability in the Bulughul Maram Fiqh mobile system is good.

Table 1 Effectiveness category

\begin{tabular}{|l|l|l|l|l|l|l|l|l|l|}
\hline \multicolumn{10}{|c|}{ Kategori Efektivitas } \\
\hline 1 & 2 & 3 & 4 & 5 & 6 & 7 & 8 & 9 & 10 \\
\hline 100 & 95 & 80 & 75 & 95 & 90 & 80 & 95 & 90 & 80 \\
\hline
\end{tabular}

KHATULISTIWA: Journal of Islamic Studies Vol. 9, No. 1. March 2019
DOI : https://doi.org/10.24260/khatulistiwa.v9i1.1384 Analysis of Knowledge Management... 
Table 2 Efficiency category

\begin{tabular}{|l|l|l|l|l|l|l|l|l|l|}
\hline \multicolumn{10}{|c|}{ Kategori Efisiensi } \\
\hline 1 & 2 & 3 & 4 & 5 & 6 & 7 & 8 & 9 & 10 \\
\hline 90 & 100 & 55 & 90 & 100 & 65 & 45 & 85 & 70 & 40 \\
\hline
\end{tabular}

Table 3 satisfaction category

\begin{tabular}{|l|l|l|l|l|l|l|l|l|l|}
\hline \multicolumn{10}{|c|}{ Kategori Kepuasan } \\
\hline 1 & 2 & 3 & 4 & 5 & 6 & 7 & 8 & 9 & 10 \\
\hline 90 & 90 & 82.5 & 80 & 65 & 60 & 70 & 70 & 70 & 65 \\
\hline
\end{tabular}

Table 4 The results of SUMI questionnaire calculations

\begin{tabular}{cccc}
\hline User & \multicolumn{3}{c}{ Responden } \\
& Effectiveness & Efficiency & satisfaction \\
\hline 1 & 70 & 40 & 60 \\
2 & 80 & 45 & 65 \\
3 & 80 & 55 & 65 \\
4 & 80 & 65 & 70 \\
5 & 90 & 70 & 70 \\
6 & 90 & 85 & 70 \\
7 & 95 & 90 & 80 \\
8 & 95 & 90 & 82.5 \\
9 & 95 & 100 & 90 \\
10 & 100 & 100 & 90 \\
Med & 90 & 77.5 & 70 \\
\hline
\end{tabular}

KHATULISTIWA: Journal of Islamic Studies Vol. 9, No. 1. March 2019
DOI : https://doi.org/10.24260/khatulistiwa.v9i1.1384 Analysis of Knowledge Management... 


\section{CONCLUSION}

The mobile application analyzed in this research is the book of bulughul fiqh maram. This mobile application displays a lot of knowledge, namely the knowledge of the bulughm jurisprudence book itself and Islamic content. the method used in this study is the method adopted from the KMSLC (Knowledge Management system Life cycle) with the Usability approach. With the existence of this knowledge-based mobile application users can view information through an Andorid smartphone so that this KMS application is useful for users.

This study uses the SUMI (Software Usability Measurement Inventory) questionnaire to obtain scores for the categories of efficiency, effectiveness and satisfaction of 90, 77.5. 70. Scores from each category are above the average SUMI provision, meaning usability on this system prototype is good. 


\section{BIBLIOGRAPHY}

Abran A, Khelifi A, Suryn W. 2003. Usability Meaning and Interpretations in ISO Standards. Software Quality Journal:323-336.

Ali N, Saputra E, Wulan R. 2016. Peran Nilai-Nilai Pendidikan Agama Islam dalam Perkembangan Teknologi Informasi Mobile di Madrasah Aliyah Manaratul Islam. Jurnal SAP. Volume 01 No 01 : 2527-967X.

Hamidi R. [Tahun Tidak Diketahui]. Epistemologi Islam: Telaah Bidang Fiqih dan Ushūl Fiqih. Prosiding Seminar Nasional Pengembangan Epistemologi Ilmu Hukum. ISBN 978-602-72446-0-3.

Hamzah AR. 2016. Agama dan Tantangan Budaya Modern Perspektif Islam. Jurnal Religion,modern culture islam. Volume 01 Nomor 02 : 2527-4430

Akri A.2015.Tantangan Pendidikan Agama Islam Di Madrasah Pada Era Globalisasi.Jurnal Madaniyah.Edisi VIII : 2086-3462.

Awad EM, Ghaziri HM. 2010. Knowledge Management. Prentice Hall.

Baihaqi MAW, Rosidi A, Syahdan SA. 2016. Analisis Usability Aplikasi E-Learning Di Fakultas Teknik dan Ilmu Komputer Unsiq Wonosobo. Jurnal PPKM III 159173: 2354869x.

Bakhri A.2015.Tantangan Pendidikan Agama Islam Di Madrasah Pada Era Globalisasi.Jurnal Madaniyah.Edisi VIII : 2086-3462

Barendregt W, Bekker MM, Bouwhuis DG, Baauw E. 2006.Identifying Usability and Fun problem in a Computer Game During First Use and After Some Practice. Human Computer Interaction Studies Journal :830-846.

Connell C, Klein JH, Loebbecke C, Powe1 P. 2001. Toward a Knowledge Management Consultation System. Knowledge and Process Management Journal Volume 8 Number 1 pp 48-54.

Diah NM, Ismail M, Ahmad S, Dahari MKM. 2010. Usability Testing for Educational Computer Game Using Observation Method. Computer and Mathematical Science Journal. Vol 1: 4244-5651.

Dwijiwo AQNES . 2014. Pengembangan IPTEK Dalam Tinjauan Hukum Islam. Jurnal Pendidikan Agama Islam, Volume 02, Nomor 01 : 1345 - 1087

KHATULISTIWA: Journal of Islamic Studies Vol. 9, No. 1. March 2019
DOI: https://doi.org/10.24260/khatulistiwa.v9i1.1384 Analysis of Knowledge Management... 
Edwards PJ, Moloney PK, Jacko JA, Sainfort F. 2008. Evaluating Usability Of Commercial Electronic Health Record: A Case Study. Human Computer Studies Journal: 718-728.

Fernandez IB, Sabherwal R. 2010. Knowledge Management: System and Processes. England: M.E. Sharpe.

Gottschalk P. 2006. Stage of Knowledge Management Systems In Police Investigations. Knowledge Based Systems Journal. Vol 19: 381-387.

Hafit H, Razak FAH, Haron H. 2011. Usability Testing with Children: What We Have Overlooked. Human Computer Interaction Journal:147-150.

Iqbal MM. 2017. Merumuskan Konsep Fiqh Islam dalam Perspektif Indonesia. Jurnal Ilmu Syariah dan Hukum. Vol. 2, Nomor 1. ISSN: 2527-8169 (P); 2527-8150 (E)

Islami I, Anisariza NU, Prasetyo KF. 2018. Penyuluhan Penerapan Ilmu Fiqih dalam Hukum Islam Sebagai Salah Satu Sumber Hukum Nasional bagi Siswa-siswi Madrasah Aliyah Negeri (MAN) 3 Jakarta. Jurnal Bakti Saintek Jurnal Pengabdian Masyarakat Di Bidang Sains dan Teknologi. Volume 2 Nomor 1: 2548-9593.

Lai LF. 2007. A Knowledge Engineering Approach To Knowledge. Management. Information Sciences an international journal. Vol. 177: 4072-4094

Mahfudin R, Firdaus Wajdi, Yusuf Ismail. 2017. Konsep pendidikan Islam KH Abdullah bin Nuh dan Relevansinya Dengan Pendidikan Islam Modern. Jurnal Studi AlQur'an. Volume 13 Nomor 02 : 2239-2614.

Malik M. 2017. implementasi aplikasi islam. Jurnal pendidikan Islam. Volume 05 nomor $02: 2303-1891$.

Muksin M. 2016. Islam Dan Perkembangan Sains \& Teknologi. Teknologi Dan Manajemen Informatika. volume 2 Nomor 4 : 1693-6604.

Muslihudin M, Didik Kurniawan, Ika Widyaningrum. 2017. Implementasi Model Fuzzy SAW Dalam Penilaian Kinerja Penyuluh Agama. Jurnal TAM. Volume 08 Nomor $01: 2579-4221$.

Nielsen J. 2012. Usability 101: Introduction to usability. Alertbox. [Internet].[diunduh 2017 Jul 17]. Tersedia pada http://www.nngroup.com/articles/usability101-introduction-to-usability/

Nonaka I. 1997. Organizational Knowledge Creation. At the Knowledge Advantage Conference Held.

KHATULISTIWA: Journal of Islamic Studies Vol. 9, No. 1. March 2019
DOI: https://doi.org/10.24260/khatulistiwa.v9i1.1384 Analysis of Knowledge Management... 
Randeree E. 2006. Knowledge Management: Securing The Future. Journal of Knowledge Management. Vol. 10 No. 4. PP 145-156.

Rhem AJ. 2006. UML For Developing Knowledge Management Systems. Boca Raton New York : Taylor \&Francis Group

Saefulloh A. 2018. Peran Pendidik Dalan Penerapan Internet Sehat Menurut Islam. Jurnal Pendidikan Islam.Volume 09 no 01: 2528-2476.

Sarayreh B, Mardawi A, Dmour R. 2012. Comparative Study: The Nonaka Model Knowledge Management. International Journal of Engineering ad Advanced Technology (IJEAT). Vol. 1.

Seffah A, Metzker E. 2009. Adoption-centric Usability Engineering. London: Springer.

Setiawan. 2018. Pengaruh Media Sosial Youtube Terhadap Perkembangan Dakwah Islam Dengan Metode Strictural Equantion Modeling (SEM).Jurnal \& Penelitian Teknik Informatika.Volume 01 Nomor 03 : 2541-2019.

Setiawan A, Suryani N, Asrowi. 2017.Urgensi Pemanfaatan Multimedia Dalam Pendidikan Islam.pendidikan islam.vol 9,No.1 : 116-129.

Sikki MI. 2010. Membangun Manajemen Pengetahuan Dalam Ketahanan Pangan. Jurnal LPPM PARADIGMA. Vol 11: No 01.

Turban E, Aroson JE, Liang TP.2007. Decision Support System and Intelligence System. Ed ke-7. United States of America: Prentice Halls.

Veenendaal E. 1998. Questionnaire Based Usability Testing. Conference Proceedings European Software Quality Week; Brussels, November 1998. Valkeenswaard: Improve Quality Services Waalreseweg.

KHATULISTIWA: Journal of Islamic Studies Vol. 9, No. 1. March 2019
DOI: https://doi.org/10.24260/khatulistiwa.v9i1.1384 Analysis of Knowledge Management... 